\title{
PATRIOTYZM KONSUMENCKI: PRÓBA SPOJRZENIA SOCJOLOGICZNEGO
}

Akcja marketingowa „Drużyna polskiego produktu” prowadzona w sieci sklepów Tesco w całej Polsce zakończyła się 6 lutego 2008 r. Kampania ta, zorganizowana przez fundację Dajesz Pracę PL, była częścią większego projektu: „Swięto polskiego produktu”. W ramach tych akcji promuje się nie tylko polskie produkty, lecz także pewien sposób patrzenia na wybory konsumenckie: fundacja chce uświadomić klientów, że ich wybór ma wpływ na polską gospodarkę i że pieniądze, które mają w portfelach, są ich rzeczywista siłą. Jednocześnie coraz częściej media poruszają temat patriotyzmu konsumenckiego, a do członków polskiego społeczeństwa coraz częściej kierowane sa apele o zwracanie uwagi podczas zakupów na - różnie rozumiany - interes narodowy. Czym jest, ,patriotyzm konsumencki”? Jak ma się on do tradycyjnego pojęcia patriotyzmu? Jakie są związki między patriotyzmem a konsumpcją i - wreszcie - czy zjawisko patriotyzmu konsumenckiego da się w ogóle wyodrębnić w życiu społecznym? Na te pytania będę starał się udzielić odpowiedzi $\mathrm{w}$ niniejszym artykule.

Rozważania należałoby zacząć od samego pojęcia ,,patriotyzm”. Nie jest ono jednorodne, brak ogólnie przyjętej definicji tego zjawiska w naukach społecznych. Problem dodatkowo utrudnia emocjonalne podejście wielu osób do tego tematu oraz jego znaczenie polityczne.

Tradycyjne postrzeganie patriotyzmu przedstawiaja Wojciech J. Burszta i Waldemar Kuligowski ${ }^{1}$. Piszą oni, że patriotyzm oznacza miłość i podporządkowanie się synów uświęconemu narodowi-ojcu. Jest to więc pewnego rodzaju związek wyobrażeniowy, przekładający na całość narodu metaforę rodziny - co istotne - patriarchalnej. Chociaż płeć patrioty nie ma znaczenia, to jednak istotę i granice patriotyzmu wyznacza zawsze moralna sytuacja synowskiego podporządkowania się ojcu. Burszta i Kuligowski zwracają także uwagę na etymologię słowa ,patriotyzm” - wywodzi się ono z greckiego patriótes (,,rodak”), a to z kolei od pátrios (,,pochodzący od tego samego ojca”). Pojmowanie całego narodu jako rodziny zdaje się tutaj kluczowe - ułatwia bowiem poświęcenia, które wynikaja z przyjęcia przez jednostkę postawy patriotycznej. Również Benedict Anderson ideę poświęceń, jakich wymaga przynależność do konkretnego narodu, wyprowadza z poczucia rodzinnej (a więc naturalnej) wspólnoty ${ }^{2}$. Naturalność tę łączy Anderson z dwoma innymi

${ }^{1}$ W. J. Burszta, W. Kuligowski, Sequel. Dalsze przygody kultury w globalnym świecie, Warszawa 2005 , s. 202-203 i 243-252.

${ }^{2}$ B. Anderson, Wspólnoty wyobrażone, Kraków 1997, s. 141-143. 
ważnymi pojęciami: bezinteresownością i brakiem wyboru. W danym narodzie po prostu się rodzimy (pomijając wyjątkowe wypadki) i to jest podstawą odczuwania przez nas więzi narodowej. Jeśli ktoś poświęca się dla narodu, to właśnie dlatego, że nie oczekuje niczego w zamian. Antonina Kłoskowska określa z kolei patriotyzm jako ,silne, naładowane emocjonalnie poczucie związku z własną grupa etniczną lub narodową" ${ }^{3}$, wymieniając cechy, które zwykle są z nim łączone, a więc: operowanie koncepcją prywatnej i ideologicznej ojczyzny, deklaracje silnego przywiązania do własnej wspólnoty narodowej i kultury, względnie dobra znajomość kanonu tej kultury, działanie dla dobra narodowej zbiorowości, preferowanie życia $\mathrm{w}$ kraju w warunkach możliwości wyboru $^{4}$. Na podstawie tych trzech ujęć można powiedzieć, że patriotyzm w ,starym” znaczeniu tego słowa to gotowość do bezinteresownego, wynikającego z wyznawanych przekonań poświęcenia się dla dobra wspólnoty narodowej - taką jego definicję przyjmę w swojej pracy.

Jednak oprócz „,starego” patriotyzmu, istnieje także „nowy” patriotyzm (a przynajmniej istnieja dwa osobne sposoby definiowania patriotyzmu). W powszechnej świadomości patriotyzm przeszłych pokoleń nie przystaje już do dzisiejszego świata, którym rządzi rynek, a dopiero później (jeśli w ogóle) polityka. Oczywiście nie ma takiej definicji patriotyzmu dostosowanego do współczesnych warunków, która zadowoliłaby wszystkich. Można jednak zaryzykować twierdzenie, że definicja taka powinna zawierać co najmniej dwa elementy: pojęcie wolności wyboru zachowań patriotycznych (czy też wolności wyboru obiektu tych zachowań) oraz pojęcie konsumpcji jako głównego pola przejawiania tychże zachowań.

Po części współgrają z tą koncepcją słowa Marcina Króla ${ }^{5}$. Pisze on w książce Patriotyzm przyszłości o własnych przeżyciach - o tym, że wielokrotnie mógł zostać za granica, co wiązałoby się z dużo lepszymi warunkami materialnymi życia niż w Polsce. Jednak Król wybrał Polskę i słowo „,wybrał” jest tutaj kluczowe. Równie ważne sa jego motywacje: była to ,tęsknota za bliskimi ludźmi, kilkoma krajobrazami i wspomnieniami”' ${ }^{6}$. Wydaje się, że w tak postrzeganym patriotyzmie nie ma miejsca na wielkie słowa (i pojęcia) w rodzaju „ojczyzna”, „naród” czy „,dziedzictwo”. Król przedstawia jeszcze jedną myśl o ogromnym znaczeniu: „Nie jest w dzisiejszym świecie tak, że ojczyzna wymaga od nas postaw patriotycznych, lecz wymagania naszej duchowej tożsamości powodują, że musimy być patriotami, jeżeli chcemy zachować swoje życie wewnętrzne"

Dziś patriotyzm przestał być wymagany; jest on jednostce potrzebny do własnego komfortu. W świecie postępującej indywidualizacji jednostka potrzebuje grupy odniesienia, potrzebuje poczucia więzi i tożsamości ${ }^{8}$. Tożsamość ta

\footnotetext{
${ }^{3}$ A. Kłoskowska, Kultury narodowe u korzeni, Warszawa 2005, s. 16.

${ }^{4}$ Ibidem, s. 382.

${ }^{5}$ M. Król, Patriotyzm przysztości, Warszawa 2004.

6 Ibidem, s. 87.

7 Ibidem, s. 95.

${ }^{8}$ Ibidem, s. 82-86; tożsamość będę tutaj rozumiał za Zygmuntem Baumanem jako ,ową szczególność, jaka odróżnia jaźń od innych jaźni, »nas« od »nich«" (Z. Bauman, Ponowoczesność jako źródto cierpień,
} Warszawa 2004, s. 51). 
na dodatek musi być uznana społecznie ${ }^{9} \mathrm{i}$-jeśli to możliwe - w miarę trwała ${ }^{10}$. Trudno znaleźć prostszy i wydajniejszy sposób budowania tożsamości jednostkowej od korzystania z ,,zasobów” tożsamości narodowej. Można w ten sposób sformować tożsamość spójną, różnorodną, uznaną społecznie; na dodatek nie wymaga to zbyt wielkiego wysiłku (pomijam tu osoby, które - z różnych przyczyn - mają problem ze zdefiniowaniem swojej przynależności do konkretnego narodu). Patriotyzm jest współczesnej jednostce potrzebny do dwóch celów: poczucia wspólnoty i budowy własnej tożsamości indywidualnej. Warto połączyć te wnioski z refleksjami Gordona Mathewsa. W swoich badaniach nad japońskimi artystami, amerykańskimi wyznawcami buddyzmu i mieszkańcami Hongkongu odkrył on szereg ciekawych tendencji dotyczących tożsamości i poczucia przynależności narodowej oraz konsumpcji. Po pierwsze, zauważył, że jego respondenci (a przynajmniej część z nich) byli przekonani, iż stwarzają swój świat z tego, co sami konsumują ${ }^{11}$. Po drugie, konstruowali oni swoje poczucie ojczyzny z tego, co znaleźli na półkach supermarketu kultury ${ }^{12}$. Mathews nazywa w związku z tym rynek ,dostarczycielem tożsamości” ${ }^{13}$. Za punkt centralny swojej tożsamości część jego respondentów uznawała elementy tradycji narodowej, często podkreślając, że o wyborze tym zadecydowały ich korzenie. Po prześledzeniu ich historii biograficznej okazywało się jednak, że był to właśnie wybór, a nie narzucony sposób budowania tożsamości, że te często podkreślane „,korzenie” nie miały wcale znaczenia ${ }^{14}$. Co więcej - większość z badanych osób akceptowała reguły rynku i z odbiorców stawała się dostarczycielami tożsamości ${ }^{15}$, nauczając tradycyjnych form zachowania czy sprzedając dzieła sztuki utrzymane w tradycyjnej konwencji danego narodu. Większość z opisywanych przez Mathewsa osób swoją tożsamość budowała na wyborach dokonanych w supermarkecie kultury, lecz tę samą funkcję moga pełnić także produkty całkiem materialne (Mathews stawia zresztą, jak się wydaje, znak równości pomiędzy supermarketem kultury a supermarketem dóbr materialnych ${ }^{16}$ ). Jedna $\mathrm{z}$ respondentek, mieszkanka Hongkongu, zastanawiając się nad swoim poczuciem przynależności kulturowej, powiedziała: „W Chinach - w tej części, którą zwiedziłam - czułam się jednak bardziej obco niż w Stanach Zjednoczonych. Kiedy idę na zakupy w Stanach, wszystkie marki są mi znane" ${ }^{17}$. Poczucie obcości, tak ważne dla tożsamości jednostki, dotyczyło w tym wypadku pola wyborów konsumenckich. Chiny są dla tej kobiety bardziej obce, ponieważ nie może tam kupić produktów, które zna ze swojego życia codziennego.

9 Ibidem, s. 219.

10 Ibidem, s. 51.

${ }^{11}$ G. Mathews, Supermarket kultury. Kultura globalna a tożsamość jednostki, Warszawa 2005, s. 149 .

${ }^{12}$ Ibidem, s. 35; Mathews uznaje supermarket kultury i supermarket dóbr materialnych za formę rynku (ibidem, s. 25).

13 Ibidem, s. 26.

14 „W supermarkecie kultury możemy wybrać tradycję, w której żyli nasi przodkowie, lecz z punktu widzenia naszych doświadczeń nie będą to korzenie, lecz wybór”, ibidem, s. 152.

15 Ibidem, s. 69.

16 Ibidem, s. 25.

17 Ibidem, s. 220. 
Łącząc refleksje Króla i Mathewsa, proponuję więc uznać „,nowy” patriotyzm za zjawisko tworzenia tożsamości przez jednostkę za pomoca wyboru z globalnego supermarketu kultury i supermarketu dóbr materialnych produktów w mniemaniu jednostki - związanych $\mathrm{z}$ narodem, do którego sama należy. Definicja tyle skomplikowana, co pozwalająca objąć swoim zasięgiem szereg zachowań konsumenckich współczesnego człowieka i, mam nadzieję, wpisująca moją refleksję nad patriotyzmem w pewne - wynikające z pragmatyzmu -ramy. Mamy więc już dwie definicje patriotyzmu, każdą odpowiadająca dwóm porządkom: dawnemu porządkowi politycznemu i współczesnemu porządkowi rynkowemu.

Należałoby teraz przyjrzeć się związkom pomiędzy patriotyzmem a społeczeństwem konsumpcyjnym, a więc społeczeństwem, które - wedle słów Zygmunta Baumana - ocenia swoich członków na podstawie ich zachowań konsumenckich ${ }^{18}$. Najłatwiej dokonać tego przez proste zestawienie, z którego wyłonią się trzy możliwe związki. Konsumpcja może więc być zjawiskiem niesprzyjającym patriotyzmowi i (odwrotnie) może być wobec niego neutralna lub (odpowiednio ukierunkowana) może stanowić jego przejaw. Pierwszy z wymienionych sposobów rozumienia związków między patriotyzmem a konsumpcją bliski jest myśli prawicowej ${ }^{19} \mathrm{i}$ wynikać może z pojmowania patriotyzmu jako zdolności do poświęceń dla ojczyzny. Któż zaś chciałby poświęcać się ojczyźnie, jeśli posiada szereg wartościowych dóbr lub przynajmniej istnieje realna możliwość ich zdobycia? Skupienie się na konsumpcji koncentruje równocześnie jednostkę na niej samej, na jej indywidualności, na tym, co ja wyróżnia, a nie na tym, co łączy ją z narodem, wspólnotą wyobrażoną (a więc nienamacalna, w przeciwieństwie do konsumowanych towarów).

Przeświadczenie o tym, że wybór konsumencki może być przejawem zachowania patriotycznego, jest natomiast charakterystyczne dla osób wierzących $\mathrm{w}$ istnienie tzw. patriotyzmu ekonomicznego. Nie jest to pojęcie jasno określone, najczęściej spotkać można je w artykułach prasowych lub doniesieniach telewizyjnych. Czasem stosuje się je w odniesieniu do polityki ekonomicznej całego państwa, najczęściej jednak dotyczy ono wyborów konsumenckich poszczególnych osób. W tym znaczeniu uznać można, że patriotyzm ekonomiczny przejawia się w świadomym kupowaniu produktów wyprodukowanych w danym kraju lub powszechnie z nim kojarzonych. Logika takiego postępowania łączy się $\mathrm{z}$,nowym” patriotyzmem (jestem Francuzem, więc kupuję francuskie wino, to mnie wyróżnia; jestem Niemcem, więc kupuję niemiecki samochód itd.). Szczególnie widać to w wypadku osób długo przebywających za granica, kupujących

\footnotetext{
18 Z. Bauman, Ptynne życie, Kraków 2007, s. 130.

19 Mówią o tym np. M. Jurek (Bez patriotyzmu możemy wytworzyć tylko wspólnotę konsumpcji, Portal Ewangelizacja.pl; dostęp: 9.06.2008); A. Raźny (Gigantyczna manipulacja, „Nasz Dziennik” z 13 marca 2008 r.) czy M. A. Cichocki (Solidarystyczne podstawy patriotyzmu, ,Znak”, nr 563, kwiecień 2002). Jurek i Cichocki podkreślaja nietrwałość wspólnoty konsumpcji, Raźny pisze zaś o konsumpcjonizmie: „kwestionujący ukierunkowanie ludzkiego życia na wartości duchowe - religijne, kulturowe, narodowe, negujący wychowanie patriotyczne”. Należy jednak uważać, by nie generalizować zbyt łatwo np. prawicowa Liga Polskich Rodzin poparła w 2004 r. postawy, które później określę mianem patriotyzmu ekonomicznego, wzywając Polaków do wykorzystania konsumpcji w celach uznanych przez siebie za patriotyczne.
} 
rodzime produkty (i tak jak Król tęskniących za wspomnieniami i krajobrazami, a pewnie też za smakiem, stylem, formą itd.).

Można jednak wyobrazić sobie połączenie tych zachowań z pojęciem „,starego" patriotyzmu. Jeśli przyjąć (choć jest to założenie odważne), że konsument we współczesnym świecie działa racjonalnie, wybierając towary, które następnie kupuje, można uznać, że zakup towarów o cechach narodowych jest metoda wsparcia jego własnego państwa wobec potęgi globalnego rynku. Jeśli konsument działa racjonalnie i zdaje sobie sprawę, że o obecnym kształcie relacji politycznych decyduje w przeważającej mierze rynek, wybór określonych produktów może zostać uznany za przejaw patriotyzmu ,starego typu”. W tym wypadku konsument nie chce swoim wyborem tworzyć własnej tożsamości, nie chce upewniać się w wyznawanych przez siebie wartościach, lecz chce wspierać gospodarczo (a więc i politycznie) swój kraj. Dodatkowej motywacji do spojrzenia $\mathrm{w}$ ten sposób na patriotyzm konsumencki dostarcza nam Burszta. Pisząc o patriotyzmie narodów środkowoeuropejskich, wysunął on tezę, że wszelki kosmopolityzm kojarzy im się źle - z internacjonalizmem (dlatego Polacy, Czesi, Węgrzy i inni z niechęcia patrzą na przejawy kosmopolityzmu w swoim otoczeniu $)^{20}$. Tak więc wybierać możemy rodzime produkty nie tylko z chęci przyczynienia się do wzrostu potęgi swojego kraju, lecz także ze strachu przed potęgą innych.

Trudno jednak nie oprzeć się wrażeniu, że taki sposób pojmowania zachowań konsumenckich w społeczeństwie konsumpcyjnym pozbawiony jest - z ekonomicznego punktu widzenia - większego sensu. Ilość produktów, spośród których wybiera przeciętny obywatel tego społeczeństwa, jest ogromna, a same sytuacje wyboru powtarzają się na każdym kroku. Nie można przecież za każdym razem kierować się patriotyzmem rozumianym w ,,stary” sposób, a kierowanie się nim od czasu do czasu - z punktu widzenia społecznego - nic nie może zmienić, wyborów jest po prostu zbyt dużo. Jak pisze Tomasz Szlendak: „prywatny wybór konsumpcyjny jest prywatny także i w tym sensie, że nie ma publicznego znaczenia. Nie konsumujemy po to, aby stworzyć jakieś lepsze społeczeństwo"21. Taka jest specyfika społeczeństwa konsumpcyjnego.

Nie możemy jednak zakładać, że każdy konsument zdaje sobie z tego sprawę, nie możemy więc także odrzucić tego punktu widzenia. Istnieje jednak jeszcze jeden argument przeciw takiemu postrzeganiu patriotyzmu konsumenckiego. „Stary” patriotyzm zakłada poświęcenie dla bliżej nieokreślonego „narodu”, „,nowy” patriotyzm to bardziej poświęcenie dla konkretnej firmy. Kupując takie, a nie inne produkty możemy mieć poczucie, że wspieramy narodowy przemysł, ale bezpośrednio wspieramy tylko właścicieli ( $\mathrm{i}$ - w pewnym stopniu - pracowników) danego przedsiębiorstwa. Firmy wykorzystują zresztą ten trend patriotyczny, tworząc marki narodowe, które wprost odwołują się do wartości związanych z poczuciem przynależności do narodu. Jak pisze Roman Rojek: „marka narodowa stanowi szczególny rodzaj marki, zorientowanej na zaspokojenie określonych potrzeb emocjonalnych klienta, wynikajacych z silnie

\footnotetext{
${ }^{20}$ W. J. Burszta, Asteriks w Disneylandzie. Zapiski antropologiczne, Poznań 2001, s. 100-105.

${ }^{21}$ T. Szlendak, Leniwe maskotki, rekiny na smyczy. W co kultura konsumpcyjna przemienita mężczyzn i kobiety, Warszawa 2005, s. 83.
} 
wykształconego u niego poczucia tożsamości i dumy narodowej” ${ }^{22}$. Tworzenie takiej marki umożliwia przedsiębiorcom wyróżnianie ich produkt spośród wielu innych, globalnych ${ }^{23}$. Ponadto może wpłynąć na zmniejszenie kosztów marketingowych $\mathrm{w}$ wyniku utożsamienia $\mathrm{z}$ ich produktami pewnych symboli związanych pierwotnie $\mathrm{z}$ narodem. Marka narodowa stanowi wreszcie odpowiedź na powstanie społeczeństwa konsumpcyjnego, w którym dóbr jest dużo, problemem pozostaje natomiast popyt na nie - aby go wytworzyć, trzeba odwoływać się do emocji klienta, a nie do argumentów racjonalnych. Można więc uznać, że tworzenie marek narodowych jest odpowiedzia na zmiany w społeczeństwach zachodniego kręgu kulturowego, których częścią jest także wytworzenie się nowego patriotyzmu.

Czy więc patriotyzm ekonomiczny bliższy jest postawie ,starego” czy „,nowego” patriotyzmu? Jednoznacznej odpowiedzi na to pytanie nie można udzielić, można jednak domniemywać, że prawda leży pośrodku. Generalizując, możemy więc wyobrazić sobie starszych ludzi kupujących lodówkę Polar po to, aby wspomóc polski przemysł, i nieco młodszych kupujących ubrania Arkadiusa, aby odzieżą polskiego projektanta skutecznie wyróżnić się na tle znajomych z garderobami od Toma Forda czy Donatelli Versace.

Skoro więc motywacji ludzi nie można $\mathrm{w}$ tym względzie jednoznacznie określić, skąd pewność, że patriotyzm ekonomiczny w ogóle istnieje w rzeczywistości? Czy kupowanie towarów wytworzonych w danym kraju lub posiadających markę z nim się kojarzącą świadczy o zachowaniach patriotycznych? Innymi słowy: czy ludzie świadomie kieruja się kryterium patriotycznym? Można przecież założyć, że zwrot konsumencki ku produktom tradycyjnie kojarzonym z danym narodem ma swoje źródła w innych zjawiskach. Skupmy się na chwilę na warunkach polskich.

Pierwszego tropu dostarczaja Burszta i Kuligowski. Piszą oni o zwrocie konsumentów ku wyrobom polskiej kuchni: „Nasyceni nareszcie oferta McDonald'sa i Burger Kinga, znudzeni już urokami kuchenek mikrofalowych i żywności typu instant, Polacy poczęli łaknąć czegoś jakościowo innego. Ale nie tego, co kosmopolityczne i ultranowoczesne [...], ale zrodzonego tutaj, [...] wypróbowanego przez spracowane ręce naszych babek" ${ }^{24}$. Ten sposób rozumowania można rozszerzyć na ogół rynku: po ponad 20 latach wolności gospodarczej Polacy mieli już aż nadto okazji, by nasycić się tym, co obce i zagraniczne. A dla rzeszy ludzi wychowanych po 1989 r. to właśnie produkty silnie nacechowane narodowo mogą stanowić ogromną nowość -ich zakup nie byłby więc przejawem patriotyzmu, lecz zwykłej logiki współczesnego rynku. Za dowód na słuszność tych twierdzeń można uznać zmianę strategii globalnych marek, które dawniej opierały atrakcyjność swoich produktów na unifikacji, dziś zaś coraz częściej dostosowują swoją ofertę do lokalnych warunków ${ }^{25}$. Firmy

\footnotetext{
${ }^{22}$ R. Rojek, Marka narodowa, Gdańsk 2007, s. 111.

${ }^{23}$ Ciekawy przykład takich działań podaje cytowany wyżej Rojek, który współtworzył strategię marketingową firmy Atlas, opartą na emocjonalnych skojarzeniach z polskością - por. ibidem.

${ }^{24}$ W. J. Burszta, W. Kuligowski, op. cit., s. 119.

${ }^{25}$ Na przykładzie korporacji McDonald's: ibidem, s. 88-96. Dobrym przykładem sa też koncerny motoryzacyjne. General Motors od lat sprzedaje takie same samochody pod marką Vauxhall w Wielkiej Brytanii i Opel w Europie kontynentalnej. Poszczególne modele bywają również sprzedawane pod
} 
zmieniają swoje oblicze z globalnego na lokalne po prostu dlatego, że im się to opłaca, i trudno uznać, że wynikiem tego jest jakiś globalny zwrot konsumentów w stronę patriotyzmu ekonomicznego. Rynek wymaga zmian i podporządkowania się wytwórców życzeniom mody. Idąc dalej tym tokiem rozumowania, można zastanowić się nad tym, czy w pewnych segmentach rynku nadawanie towarom nowych „,narodowych” znaczeń nie wynika z faktu, że znaczenia te sa dla współczesnego konsumenta nowe. A to, co nowe we współczesnej kulturze, ma dużą szansę stać się modne i - co za tym idzie - bardzo dochodowe. Dla przynajmniej części dzisiejszych dwudziestokilkuletnich konsumentów, żywionych całe życie hamburgerami, pizzami i zupkami chińskimi, tradycyjne dania kuchni polskiej sa po prostu nieznane i dlatego zyskują na atrakcyjności ${ }^{26}$.

$\mathrm{Z}$ punktu widzenia globalnego rynku moda na kuchnie narodowe, trunki narodowe, narodowych projektantów mody itd. może być uznana za - używając słów Jeana Baudrillarda - przemysłową produkcję różnic ${ }^{27}$, co pozwala na zintegrowanie społeczeństwa i utrzymanie w nim odpowiedniej hierarchiczności. Patrząc z tego punktu widzenia, każda różnica w zakresie konsumpcji jest funkcjonalna, także ta pomiędzy konsumpcją produktów „narodowych” a ,globalnych".

Innym wyjaśnieniem popularności polskich produktów może być odczuwana przez rzesze ludzi nostalgia. Producenci moga korzystać bądź z tego, że dane produkty dostępne są od wielu lat (sprzedawane były także w czasach PRL-u), bądź z tego, że dużej liczbie konsumentów kojarzą się z okresem dzieciństwa i młodości ${ }^{28}$. Przykładami polskich marek święcących sukcesy, najprawdopodobniej właśnie z tego powodu, sa kosmetyki Brutal, akumulatory firmy Centra czy płyn do mycia naczyń Ludwik. Sztandarowym przykładem ponownego wprowadzenia na rynek produktu kojarzącego się ze „starymi dobrymi czasami” jest Polo Cockta produkowana przez firmę Zbyszko. Na podobnej zasadzie Volkswagen w $1998 \mathrm{r}$. wprowadził do sprzedaży model New Beetle, a więc samochód mający przypominać słynnego garbusa, a w 2011 r. jego kolejne wcielenie pod nazwa po prostu Beetle. Jednak New Beetle największy sukces odniósł w Stanach Zjednoczonych, gdzie jego protoplasta kojarzony był przede wszystkim z rewolucją obyczajową lat sześćdziesiątych, a nie w Niemczech (czy mówiąc szerzej - w Europie Zachodniej), gdzie kojarzy się go raczej z latami powojennej odbudowy ${ }^{29}$. Droga wytyczona przez Volkswagena poszły kolejne koncerny, jak choćby Ford (z modelami GT i trzynasta generacja

różnymi markami i nazwami w różnych rejonach świata. Podobną strategię stosują również inne koncerny, czego najnowszym przykładem jest wprowadzenie w 2011 r. na rynek w Europie Fiata Freemonta, co nastąpiło po przejęciu przez Fiata koncernu Chrysler (który z kolei ten sam model sprzedawał jako Dodge Journey). Przykłady można by mnożyć, a w grę wchodzi przecież również wykorzystywanie wspólnych podzespołów i elementów w tworzeniu zupełnie odrębnych modeli w ramach jednego koncernu.

${ }^{26} \mathrm{O}$ modzie na obcość we współczesnej kulturze popularnej, choć nieco z innej strony, zob. M. Krajewski, Kultury kultury popularnej, Poznań 2003, s. 105-125.

${ }_{27}$ J. Baudrillard, Społeczeństwo konsumpcyjne. Jego mity i struktury, Warszawa 2006, s. 104-114.

${ }^{28}$ O nostalgii za PRL-em zob. M. Krajewski, op. cit., s. 205-245.

${ }^{29}$ Ciekawie na temat związków między tożsamością narodową a przemysłem motoryzacyjnym, na przykładzie Wielkiej Brytanii, pisze T. Edensor, Tożsamość narodowa, kultura popularna $i$ życie codzienne, Kraków 2004, s. 161-166. 
Thunderbirda) czy - to najnowszy przykład - Fiat z produkowanym w Polsce modelem $500^{30}$. Podobne przedsięwzięcia od lat realizuja mniejsze firmy motoryzacyjne z całego świata, a popularność produkowanych przez nie modeli w stylu retro wynika właśnie z poczucia sentymentu wśród kupujących. Różnica polega na tym, że Amerykanie moga kupować volkswageny New Beetle, ponieważ na ich rynku produkty z całego świata dostępne były nieprzerwanie. Polacy pija Polo Cocktę, ubierają się w Wólczance czy Próchniku, kupuja $\mathrm{w}$ sklepach Społem nie $\mathrm{z}$ powodu patriotyzmu konsumenckiego, lecz ze zwykłego sentymentu lub przyzwyczajenia. A że są to wszystko marki polskie? Cóż - to wynik specyfiki polskiej historii, a nie nastawień konsumenckich Polaków.

W rozważaniach o patriotyzmie konsumenckim warto wspomnieć o danych empirycznych na jego temat. I tak z badań TNS OBOP, których wyniki opublikowano 10 marca 2004 r., wynika, że tylko 5\% ankietowanych zwracało uwage przy codziennych zakupach na to, czy kupuje polski czy zagraniczny produkt ${ }^{31}$. Trzy miesiące później do takiego zachowania przyznawało się już $13 \%$ respondentów ${ }^{32}$. Gdy w badaniu dla „Życia Handlowego” zapytano o tę kwestię wprost, aż $81 \%$ osób stwierdziło, że ,stara się kupować produkty krajowe, jeśli ma taką możliwość” ${ }^{33}$. Można uznać, że rozdźwięk między tymi danymi wyraża niedoskonałość ankietowej techniki badania patriotyzmu konsumenckiego. Ciekawym sposobem zrealizowania badań byłoby przeprowadzenie wywiadów z osobami kupującymi w wybranym sklepie, w którym produkty polskie byłyby wyraźnie oznaczone i wyróżnione na tle innych. Takie badanie nie pozwalałoby oczywiście na zachowanie reguł reprezentatywności próby, być może jednak dałoby jaśniejsze dane na temat tego, jakie motywacje rzeczywiście wpływają na ludzi w momencie zakupu.

Według badań przeprowadzonych w kwietniu $2008 \mathrm{r}$. przez Instytut Badania Opinii RMF FM na ogólnopolskiej grupie 300 osób w wieku od 18 do 50 lat Polacy wśród cech prawdziwego patrioty dopiero na dziewiątym miejscu klasyfikowali „kupowanie jak najczęściej polskich produktów”. W komentarzu do tego badania możemy przeczytać, że „,patriotyzm [wg Polaków - dop. Ł.S.] powinien zatem znajdować wyraz w zakresie obowiązków i powinności, ale już nie w sferze rozrywki i konsumpcji” ${ }^{34}$. Większe uznanie wśród badanych zyskały takie zachowania, jak: uczciwe płacenie podatków (czwarta pozycja), posiadanie flagi narodowej (szósta pozycja) czy manifestowanie swojej polskości za granica (siódma pozycja). Na pierwszym miejscu znalazł się udział we wszystkich wyborach.

Dziennikarze dość często narzekają, że Polacy różnią się od innych narodów w zakresie postrzegania konsumpcji jako przejawu patriotyzmu. „Gazeta Wyborcza” podaje: „Na przykład w Irlandii współczynnik osób, które kupuja

${ }^{30}$ Co ciekawe, próba ponownego wprowadzenia na rynek marki Junak, pod którą w PRL-u sprzedawano motocykle, nie powiodła się (o powodach zob. Ł. Gazur, Jak sprzedać sentyment do PRL, „Dziennik Polski” z 21 sierpnia 2007 r.).

${ }^{31}$ TNS OBOP, Jak kupujemy leki, a jak inne produkty, www.tnsglobal.pl.

${ }^{32}$ TNS OBOP, Polskie zachwalali, wielu przekonali, www.tnsglobal.pl; TNS OBOP łączy ten wzrost z przeprowadzoną akcją ,Kupując polskie produkty dajesz pracę”.

${ }^{33}$ R. Olesiński, Cenny patriotyzm konsumencki, „Gazeta Prawna” z 25 lutego 2004 r.

${ }^{34}$ Kto Ty jesteś? Polak!, Instytut Badania Opinii RMF, www.rmf.fm/instytut/ (dostęp: 4.08.2011). 
towary wyprodukowane we własnym kraju, wynosi około 50 procent, podobnie jest w innych państwach Europy Zachodniej. W Polsce wskaźnik ten wynosi 5 procent” ${ }^{35}$. „Gazeta Prawna” pisze z kolei: „,niewielu Niemców jeździ samochodem innym niż niemiecki” i ,59 proc. dorosłych Irlandczyków ma świadomość, że kupowanie produktów i usług wyprodukowanych w Irlandii polepsza sytuację na rynku pracy w tym kraju”. Najciekawsze wydaje się zdanie: „Japończykom z kolei od dziesięcioleci wpajano, że decyzja o zakupie czegoś $\mathrm{z}$ importu wywołuje podobne rozterki jak współpraca $\mathrm{z}$ obcym wywiadem" 36 . O namawianiu mieszkańców szeroko pojętego Zachodu do konsumpcji rozumianej jako wspomaganie własnego kraju (a więc zgodnie ze „,starym” patriotyzmem”) pisze też ,Gazeta Wyborcza”. Pojawia się tutaj nawet wątek militarystyczny: „Amerykańskie reklamy tego okresu [w latach 50. XX w. - przyp. Ł.S.] odwoływały się na przykład do retoryki zimnowojennej: płatki śniadaniowe miały pomóc wychowywać zdrowych żołnierzy, którzy pokonają komunizm, domki jednorodzinne miały umożliwić większe rozproszenie miast (a więc odporność na atomowe uderzenie), a szybkie samochody miały pomóc $\mathrm{w}$ ewakuacji z zagrożonych terenów. W podobny sposób konsumpcję jako akt patriotyzmu zachwalały reklamy w Europie - apelując do gospodyń domowych o wychowywanie tych, którzy odbuduja miasta z ruin i staną na straży granic" ${ }^{37}$. W Polsce w czasach PRL-u tego typu kampanii nie było (bo i po co, skoro produktów z Zachodu było jak na lekarstwo, a produkty bratnich państw były ,ideologicznie” równie wartościowe, co polskie?). Dziś zgodnie $\mathrm{z}$ prawem Unii Europejskiej tego typu kampanie prowadzić moga tylko niezależne fundacje ${ }^{38}$.

W literaturze, szczególnie ekonomicznej, pojęcie etnocentryzmu konsumenckiego wydaje się zbieżne z omawianym w niniejszym tekście patriotyzmem konsumenckim. Jak zwraca uwagę Rojek: „na gruncie stosunków rynkowych jest zjawiskiem odpowiadajacym patriotyzmowi gospodarczemu" ${ }^{39}$. Warto zwrócić uwagę na ten jego aspekt - odwołuje się on bowiem bezpośrednio do tradycyjnego sposobu postrzegania patriotyzmu. Równocześnie przywołuje skojarzenia z czasami sprzed globalizacji gospodarczej na współczesną skalę, gdy powszechnym zjawiskiem była ochrona przez państwa narodowe własnej gospodarki, np. przez cła ochronne. Patriotyzm konsumencki byłby w tym rozumieniu działaniem podobnym, opierającym się na tej samej logice, choć majacym miejsce w skali mikro, a nie makro; na gruncie działań indywidualnych jednostek i ich wyborów, a nie polityki państwowej. Przy okazji warto zauważyć, że w badaniach nad etnocentryzmem konsumenckim pojawia się również kwestia czegoś, co nazwałbym patriotyzmem lokalnym, a więc preferowaniu produktów z danego regionu wobec szerokiej oferty nie tylko globalnej, lecz także ogólnokrajowej ${ }^{40}$. Skrajnym przykładem wykorzystania

${ }^{35}$ Polacy nie sa ekonomicznymi patriotami, ,Gazeta Wyborcza” z 26 grudnia 2007 r.

${ }^{36}$ R. Olesiński, op. cit.

${ }^{37}$ W. Orliński, Jak wymyślono wielkie żarcie, ,Gazeta Wyborcza” z 26 maja 2006 r.

${ }^{38}$ Strona internetowa Fundacji Dajesz Pracę PL, http://www.dajeszprace.pl/ (dostęp: 9.06.2008).

${ }^{39}$ R. Rojek, op. cit., s. 55.

${ }^{40} \mathrm{Na}$ ten aspekt zachowań konsumentów piwa w Polsce zwracają uwage badacze z Politechniki Białostockiej i Uniwersytetu Keele - D. Siemieniako et al., National and Regional Ethnocentrism: A Case Study of Beer Consumers in Poland, „British Food Journal” 113, 2011, nr 3, s. 404-418. 
w działalności marketingowej strategii opartej na patriotyzmie lokalnym jest kontrowersyjna reklama piwa Piast, w której posłużono się hasłem „Jedno miasto. Jeden Klub. Jeden Piast”, przywołujące skojarzenia z nazistowskim „Jeden naród, jedna Rzesza, jeden wódz" ${ }^{41}$.

$\mathrm{Na}$ różnice między zachowaniami konsumenckimi Polaków a obywateli krajów zachodnich zwrócili uwagę Andrzej Falkowski, Bogdan Rożnowski i Tadeusz Witkowski ${ }^{42}$. Badali oni przejawy etnocentryzmu ujawniające się przy zakupach proszku do prania: 179 badanym osobom przedstawiano pary proszków z następujących grup: proszki polskie (produkowane w Polsce przez polskie firmy), proszki zagraniczne, proszki niejednorodne (produkowane w Polsce, ale przez zagraniczną firmę). Badani wybierali jeden proszek z pary, a następnie określali stopień pewności swojego wyboru. Etnocentryzm zbadano osobno za pomoca specjalnej skali. W opisie badań sporządzonych przez Andrzeja Falkowskiego i Tadeusza Tyszkę czytamy, że „,konsumenci niskoetnocentryczni wyraźnie odróżniają firmy polskie [...] od firm zagranicznych [...], identyfikują się z zagranica, a odrzucają produkty polskiego pochodzenia przypuszczalnie preferuja zachodni styl życia i ignorują polska produkcję" ${ }^{43}$. Konsumenci wysokoetnocentryczni zaś ,,wydają się znacznie bardziej otwarci na towary różnych firm. Nie występuje u nich ostre zróżnicowanie na firmy polskie i zagraniczne" ${ }^{44}$. Oznacza to, że z postawa patriotyzmu konsumenckiego nie łączy się rzeczywista wiedza o rynku, a deklarowane postawy nie przekładają się na konsumenckie wybory. W komentarzu do tych badań autorzy piszą: „Prezentowane rezultaty są wyraźnie odmienne od wyników badań przeprowadzonych w kulturze zachodniej [...] etnocentryczni konsumenci amerykańscy, francuscy, niemieccy i japońscy w porównaniu z konsumentami nieetnocentrycznymi o wiele ostrzej różnicują krajowe i zagraniczne towary i preferuja te pierwsze" ${ }^{45}$.

Istnieje jeszcze jedno zjawisko, które może zaprzeczać powszechności patriotyzmu konsumenckiego wśród Polaków. Polega ono na wykorzystywaniu przez polskie firmy obcobrzmiących nazw, najprawdopodobniej w celu uzyskania pozytywnych skojarzeń z jakością produktu i zwiększenia sprzedaży. Liczba marek stosujących tę taktykę (dzisiaj lub tylko w przeszłości) jest imponująca: Americanos, Diverse, Reserved, House, Home\&You, Top Secret, Tatuum, żeby wymienić tylko te najbardziej znane.

W podsumowaniu należy stwierdzić, że w Polsce istnieją zachowania, które uznać można za przejawy patriotyzmu konsumenckiego. Skala tego zjawiska pozostaje niewiadoma, jednak przypuszczalnie nie jest ona zbyt duża. Nawet jeśli w niektórych wypadkach wybór produktu krajowego motywowany jest w inny sposób, motywacje patriotyczne u współczesnych konsumentów przynajmniej od czasu do czasu - dają o sobie znać. Sam fakt, że istnieje grupa osób, która spełnia definicyjne założenia konsumenta patrioty, pozwala nam uznać, iż zjawisko to ma miejsce w życiu społecznym i choćby z tego powodu

${ }^{41}$ J. Sawka, Piast tylko dla Polaków, „Gazeta Wyborcza” z 26 lipca 2011 r.

${ }^{42} \mathrm{Za}$ : A. Falkowski, T. Tyszka, Psychologia zachowań konsumenckich, Gdańsk 2006.

${ }^{43}$ Ibidem, s. 89.

${ }^{44}$ Ibidem, s. 90.

${ }^{45}$ Ibidem. 
warte jest badań i refleksji. Nie sposób jednoznacznie ocenić, czy opisywane wyżej zachowania wypływają z poczucia patriotyzmu pojmowanego na „,nowy” czy też na ,stary” sposób. Najprawdopodobniej występują tu obydwie sfery motywacji, o których pisałem wcześniej. Patriotyzm konsumencki stał się impulsem do tworzenia strategii marketingowych $-\mathrm{z}$ jednej strony ta postawa staje się więc coraz szerzej znana, z drugiej zaś dość oczywiste stają się ściśle finansowe efekty jej wykorzystania przez przedsiębiorców.

mgr Łukasz Skoczylas

Uniwersytet im. Adama Mickiewicza w Poznaniu

luke@amu.edu.pl

\section{CONSUMER PATRIOTISM: A SOCIOLOGICAL PERSPECTIVE}

\section{Summary}

The paper discusses the topic of consumer patriotism and is an attempt to connect it with the construct of the old traditional, and the new type of patriotism. It shows that consumer patriotism can be analysed from both perspectives. It also describes how local entrepreneurs are using consumers' patriotic attitudes in their marketing campaigns. 
Copyright of Journal of Law, Economics and Sociology is the property of Faculty of Law and Administration of Adam Mickiewicz University in Poznan and its content may not be copied or emailed to multiple sites or posted to a listserv without the copyright holder's express written permission. However, users may print, download, or email articles for individual use.

Właścicielem praw autorskich do „Ruchu Prawniczego, Ekonomicznego i Socjologicznego” jest Wydział Prawa i Administracji Uniwersytetu im. Adama Mickiewicza w Poznaniu. Zawartość czasopisma nie może być kopiowana, przesyłana do innych stron internetowych bądź zamieszczana na blogach bez pisemnej zgody wydawcy. Niemniej artykuły można drukować, kopiować lub przesyłać w formie elektronicznej na własny użytek. 